Jurnal Ekonomi Syariah Teori dan Terapan p-ISSN: 2407-1935, e-ISSN: 2502-1508. Vol. 8 No. 5 September 2021: 630-640; DOI: 10.20473/vol8iss20215pp630-640

\title{
ANALYSIS OF THE INFLUENCE OF SHARIA FINANCIAL SECTOR ON INDONESIAN NATIONAL INCOME 2011-2020
}

\section{ANALISIS PENGARUH SEKTOR KEUANGAN SYARIAH PADA PENDAPATAN NASIONAL INDONESIA TAHUN 2011-2020}

\author{
Naufal Haidar Farras, Darwanto \\ Program Studi Ekonomi Islam - Fakultas Ekonomika dan Bisnis - Universitas Diponegoro \\ naufalfarras.undip@gmail.com*,darwanto@live.undip.ac.id
}

\begin{abstract}
ABSTRAK
Penelitian ini bertujuan untuk menganalisis pengaruh variabel sektor keuangan syariah terhadap Pendapatan Nasional Indonesia yang masih terkenal belum maksimal. Variabel sektor keuangan syariah terdiri dari indeks saham syariah, reksadana syariah, obiligasi syariah, serta perbankan syariah. Variabel Pendapatan Nasional Indonesia menggunakan data Produk Domestik Bruto Indonesia. Penelitian ini menggunakan metode ARDL (Autoregression Distributed Lag) yang mengukur pengaruh dalam jangka pendek maupun panjang secara parsial maupun stimultan. Penelitian ini menggunakan data triwulan yang diperoleh dari Statistik Saham Syariah, Statistik Reksadana Syariah, Statistik Sukuk Syariah, serta Statistik Perbankan Syariah dari Otoritas Jasa Keuangan. Sedangkan data Produk Domestik Bruto Indonesia didapatkan dari Kementerian Perdagangan Republik Indonesia periode waktu antara Januari 2011 sampai dengan Desember 2020. Hasil penelitian secara parsial menunjukkan bahwa dalam jangka pendek, perbankan syariah berpengaruh positif positif terhadap PDB, saham syariah dan reksadana syariah berpengaruh negatif terhadap $P D B$, sedangkan obligasi syariah tidak berpengaruh terhadap PDB. Dalam jangka panjang, perbankan syariah berpengaruh positif positif terhadap PDB, saham syariah dan reksadana syariah berpengaruh negatif terhadap $P D B$, sedangkan obligasi syariah tidak berpengaruh terhadap PDB. Secara simultan dalam jangka pendek dan jangka panjang sektor keuangan syariah tidak memiliki hubungan kointegrasi jangka Panjang terhadap Produk Domestik Bruto Indonesia.
\end{abstract}

Kata Kunci: Indeks Saham Syariah, Reksadana Syariah, Obligasi Syariah, Perbankan Syariah, Produk Domestik Bruto.

\section{ABSTRACT}

This study aims to analyze the effect of Islamic financial sector variables on Indonesia's National Income which is still not maximized. The Islamic finance sector variables consist of Islamic stock index, sharia mutual funds, sharia bonds, and sharia banking. The Indonesian National Income Variable uses Indonesia's Gross Domestic Product data. This study uses the ARDL (Autoregression Distributed Lag) method which measures the effect in the short term either partially or simultaneously. This study uses quarterly data obtained from Sharia Stock Statistics, Sharia Mutual Fund Statistics, Sharia Sukuk Statistics, and Sharia Banking Statistics from the Financial Services Authority. Meanwhile, Indonesia's Gross Domestic Product data was obtained from the Ministry of Trade of the Republic of Indonesia for the period between January 2011 to December 2020. The partial results show that in the short term, Islamic banking has a positive effect on GDP, Islamic stocks and Islamic mutual funds have a negative effect on GDP, while Islamic bondon has no effect on GDP. In the long term, Islamic banking has a positive positive effect on GDP, Islamic stocks and Islamic mutual funds have a negative effect on GDP, while Islamic bonds have no effect on GDP. Simultaneously, in the short and long term, the Islamic finance sector does not have a long-term cointegration relationship with Indonesia's Gross Domestic Product.

Keywords: Sharia Stock Index, Sharia Mutual Funds, Sharia Bonds, Sharia Banking.
Informasi artikel Diterima: 05-05-2021 Direview: 11-09-2021 Diterbitkan: 30-09-2021

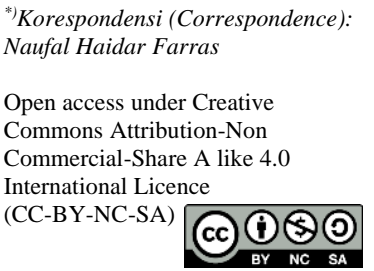




\section{INTRODUCTION}

In an economy, there is a state's responsibility to create economic growth sustainably. Economic growth is a critical indicator for seeing the success of government development and performance in a country. Each country will strive to create optimal economic growth to reduce social inequality in society (Kakwani, Son, and Bank 2003). One of the main objectives of economic growth is reducing the level of poverty achieved through economic growth or redistribution of income. However, conditions in developing countries show problems when economic growth is accompanied by the increasing number of people living under the poverty line. This certainly contradicts the purpose of this economic growth.

Table 1.

Indonesia's Economic Growth and GDP Statistics

\begin{tabular}{ccc}
\hline Year & Economic growth & GDP at Constant Prices (Billions) \\
\hline 2013 & $5,56 \%$ & $8.156 .497,80$ \\
2014 & $5,02 \%$ & $8.564 .866,60$ \\
2015 & $4,79 \%$ & $8.982 .517,10$ \\
2016 & $5,02 \%$ & $9.434 .613,40$ \\
2017 & $5,07 \%$ & $9.912 .703,60$ \\
2018 & $5,17 \%$ & $10.425 .316,30$ \\
2019 & $5,02 \%$ & $10.949 .037,80$ \\
2020 & $-2,90 \%$ & $10.722 .442,70$ \\
\hline
\end{tabular}

Source: Central Bureau of

Statistics 2020The financial sector plays a critical role in increasing national income and encourages economic growth in a country. This can be realized because the financial sector can move the growth of the real sector. This can be seen from the ability of the financial sector to mobilize savings. At present, the financial sector is centralized in the conventional financial sector and the Islamic financial sector. One type in the financial sector is the banking and investment sector; the banking sector is an institution that collects and channels community funds from those who aim to support the implementation of national development to increase equitable development and results. At the same time, investment or capital formation is one component that significantly affects economic growth. The level of investment must be greater than the level of consumption so that economic growth can run well. If the level of high investment, the level of poverty and unemployment will drop.

In the Islamic financial sector, there are various instruments such as Islamic banking, Islamic capital markets, Islamic mutual funds, to sharia bonds. The instrument is expected to be able to improve the Islamic financial sector to increase national income stimulates. However, there are significant problems: the slow growth of financial sector instruments, namely investment both conventional and sharia. According to the Indonesia Investment Coordinating Board (BKPM) data, investment growth slowed from above 10 percent in 2017 to around 4 percent in 2018. This caused economic growth throughout 2018 to not reach the target. This is caused by internal and external factors like rupiah currency turmoil and superpower trade war. However, this is undoubtedly homework for the Indonesian government to continue to boost investment to increase national income in Indonesia.

The development of sharia investment in Indonesia in the last five years has shown positive growth for the Indonesian economy. but it turns out that there are still several problems that can hinder the growth of sharia investment itself, one of which is the existence of speculation carried out by unscrupulous speculators in Indonesia. In addition, the problem that also occurs is the role of Islamic banking for economic growth which is still relatively small, which is $6.51 \%$ in 2020 from all banks in Indonesia. This is due to the small share of Islamic banking and financing which is still dominated by murabahah contracts or the consumptive sector. In fact, the characteristics of Islamic banking should lie in the mudharabah contract, namely profit sharing to focus on the productive financing sector. The Financial Services Authority in 2020 stated that the total assets of Islamic banking reached Rp608.90 trillion or $6.51 \%$ of the total assets of the national banking industry. Meanwhile, the capitalization value of shares classified as sharia securities was recorded at IDR 3,352.26 trillion, or 47.2\% of the total capitalization of shares listed on the Indonesia Stock Exchange (IDX). Meanwhile, the outstanding 
value of State Sukuk reached Rp971.5 trillion or $18.58 \%$ compared to the total outstanding Government Securities (SBN).

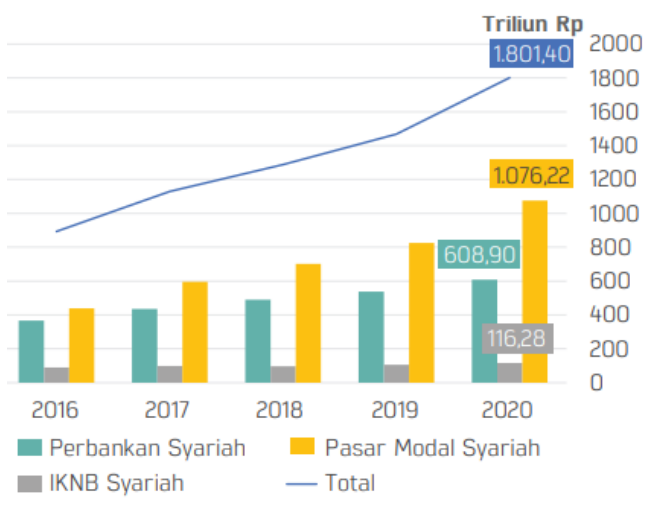

Source: Financial Services Authority 2020

Figure 1.

Growth in Total Islamic Financial Assets in Indonesia

Dalam menanggapi hal tersebut, pemerintah telah melakukan beberapa kebijakan untuk mendorong investasi sektor moneter di Indonesia salah satunya adalah intervensi Bank Indonesia (BI) untuk menekan pelemahan rupiah sempat mencapai angka Rp14.900 dinilai sukses memberikan sentimen positif bagi para pelaku pasar yang beramai-ramai. melakukan investasinya. Selain itu, pemerintah juga meluncurkan seri sukuk ritel guna mendorong kebijakan ekspansif fiskal dalam melakukan pembangunan infrastruktur guna meningkatkan pertumbuhan ekonomi Indonesia.

Al-tamimi (2018) said a statistically significant influence between Islamic banking and development economics in responding to this. Although the achievement of Islamic bank assets and deposits is relatively high in terms of assets and deposits, the contribution of Islamic banks in Jordan to economic development is still marginal compared to conventional banking. In addition, Abduh and Omar (2012) found evidence that the development of Islamic finance has a positive and essential role in the long term and is related to economic growth and capital increase. Domestic financing provided by the Islamic banking sector has contributed to Indonesia's economic growth.

Islamic banking has proven to be effective as a financial intermediary that facilitates funds transfer from surplus households to deficit households. The relationship between Islamic financing and economic growth in Indonesia plays a role in stimulating economic growth and encouraging the development of Islamic banking in Indonesia. In another study, Beik (2011) said that the issuance of state Sukuk is currently dominated by efforts to patch the State expenditure budget (APBN) deficit in infrastructure development to achieve stable national income and increasing economic growth. This shows that Sukuk can affect national income so that it continues to be stable.

The weakness of existing research is that no research raises the influence of the Islamic financial sector in the form of Islamic stocks, Islamic mutual funds, and Islamic bonds simultaneously and analyzes their impact on national income in Indonesia. In addition, most of these studies use descriptive research methods not to describe whether the financial sector has a significant effect on national income in Indonesia partially. The lack of literature and research on the effects of conventional and Islamic Investment is deplorable because currently, the government is continuing to boost investment growth through the "Yuk Nabung Saham" program and other programs. So it is hoped that this research will become a reference for the government, the Indonesia Investment Coordinating Board (BKPM), and securities in Indonesia to create innovations to increase Investment in Indonesia, both sharia and conventional, to increase national income in Indonesia.

The significant growth of Islamic financial institutions and high economic growth at the same time can be used as a study of whether the Islamic banking sector, which has now become one of the banking sectors in Indonesia, actually makes an empirical contribution to national income in Indonesia and of course is committed to national economic growth in the long run. To do this, an analysis of dynamic interactions between the Islamic financial sector and national income is needed by using a model of whether the Islamic financial sector affects national income. Based on these thoughts, research on the analysis of the influence of the Islamic financial sector, namely Islamic banking, Islamic mutual 
fund stocks, and Islamic bonds on national income in Indonesia, needs to be done.

\section{THEORETICAL BASIS AND HYPOTHESIS DEVELOPMENT}

Schumpeter (2013) said there are at least four possible approaches that can explain the causal relationship between the financial sector and growth, namely:

1. The financial sector is a determining factor for economic growth (finance-led growth hypothesis), commonly called the supply-leading view.

2. The financial sector follows the economic growth (growth-led finance hypothesis) or socalled demand-following view.

3. The interplay between the financial sector and growth or what is commonly called the bidirectional causality view.

4. The financial sector and growth are not interrelated or commonly called the independent hypothesis.

Rama (2013) reveals that these empirical results prove that the growth of Islamic banking in Indonesia can encourage high economic expansion through products and services compatible with sharia. Of course, this is in line with the character of Islamic banking itself, which is very pro and emphasizes the real economic sector. Therefore, the researcher develops a hypothesis:

$H \mathrm{H}=$ It is suspected that Islamic banking affects national income.

Nasution (2015) said that the capital market has an essential role in a country's economy because the capital market carries out two functions, namely first as a means of financing business or as a means for companies to obtain funds from the investor community. Funds obtained from the capital market can be used for business development, expansion, additional working capital. Both capital markets are a means for people to invest in financial instruments. Therefore, the researcher develops a hypothesis:

$H 2$ = It is suspected that the Sharia Stock Index affects national income.

Meanwhile, Fauzan and Suhendro (2019) said that the development of the capital market in Indonesia, which is reflected in the leading indicators of the capital market, which continues to grow from year to year, can drive economic growth by making investment activities begin to increase. This increase was driven, among others, by developments in the Islamic capital market, including Islamic mutual funds. The increasing strength of the role of the Islamic capital market in shaping the capitalization of the Indonesian capital market indicates that the Islamic capital market has a significant role in driving Indonesia's economic growth. Therefore, the authors have a hypothesis:

$H 3=$ It is suspected that Islamic mutual funds affect national income.

Nur Faroh (2016) said that Sukuk fosters private sector participation in financing projects that are useful for the public interest, being an instrument in promoting domestic and international investment, and being beneficial for the fiscal decentralization process. This shows that Sukuk can affect national income so that it continues to be stable. Therefore the authors develop a hypothesis:

$H 4=$ It is suspected that Islamic bonds affect national income.

Kassim (2016) measures the influence of the Islamic financial sector in Malaysia. This study indicates that Islamic banks in Malaysia effectively carry out the role of financial intermediation in collecting and channeling funds for productive investment activities. Based on the hypothesis partially, the authors develop a hypothesis simultaneously that:

H5 = It is suspected that the Islamic financial sector affects national income.

\section{RESEARCH METHODS}

The dependent variable in this study is Gross Domestic Product at constant prices in Indonesia. Meanwhile, Islamic banking, Islamic mutual funds, Islamic stock index, and Islamic bonds are the independent variables. The data collection method used in this research is documentation and literature study. Secondary data collection for the national income variable was obtained through the official website of the Ministry of Trade of the Republic of Indonesia and variables outside the national income 
variable were obtained from monthly financial reports through the OJK official website. This study uses a quantitative analysis method that aims to determine the effect of the Islamic finance sector (Islamic banking, Islamic bonds, Islamic mutual funds) on national income in Indonesia in 2011-2020. The analytical tool used in this study is the Autoregressive Distributed Lag (ARDL) method.

\section{Stationarity Test}

One of the formal procedures for stationarity testing is the unit root test. David Dickey and Wayne Fuller developed this test, referred to as the Augmented Dickey-Fuller (ADF) Test. Suppose a time series data is not stationary at the level (zero-order, I (0)). In that case, the stationarity of the data can be searched through the following order, namely first-order or I (1) (first difference), or secondorder or I (2) (second difference).

Because this study uses the ARDL method, all variables must be stationary at the level (I (0)) or first order (I (1)). If these conditions are not met, or some variables are stationary in second-order (I (2)), it will cause the ARDL method to be invalidated. The hypothesis for this test is:

H0: there is a unit root (not stationary).

H1: no unit root (stationary).

\section{Cointegration Test}

(Shin and Smith 2001) introduced the bound-testing cointegration test, which is a test to find cointegration between variables in the model. The F-statistic test is used in bound-testing on the best model. The best model will be obtained by looking at the value of the Schwartz-Bayesian criteria (SBC) and Akaike's information criteria (AIC). SBC and AIC values are used to determine the lag-optimum variable. SBS is the model that chooses the minor possible lag length, while AIC chooses the maximum lag length.

\section{ARDL Method}

Rosadi (2011) said that the distributed lag model is if the regression model includes not only the present value but also the past value (lag) of the explanatory variable (X). Meanwhile, autoregressive distributed lag is a model that includes past values (lag) of the dependent variable among the explanatory variables. According to Gujarati (2003), a regression model that includes a variable value that explains the present value or the past value (lag) of the dependent variable as one of the explanatory variables is called Autoregressive Distributed Lag (ARDL).

\section{RESULTS AND DISCUSSION Stationarity Test}

The unit root test or stationarity test of the four variables (GDP, Banking, Mutual Funds, and Sukuk) is stationary at first difference, using both the Augmented Dickey-Fuller (ADF) and Phillips Perron models. The variable stock is static at level (at level). This is indicated by a probability value that is greater than $\alpha(5 \%)$. Because the variable is stationary at the 1st difference and one variable is static at the level (at level), the analysis can use in this model is to use the ARDL (Autoregressive Distributed Lag) model.

Table 2.

Variable Unit Root Test Results

\begin{tabular}{cccccc}
\hline \multirow{2}{*}{ No. } & \multirow{2}{*}{ Variable } & \multicolumn{2}{c}{ Augmented Dickey-Fuller (ADF) } & \multicolumn{2}{c}{ Phillips Perron } \\
\cline { 3 - 5 } & & at level & $1^{\text {st }}$ difference & at level & $1^{\text {st }}$ difference \\
\hline 1. & GDP & 0.9985 & $0.0000^{*}$ & 0.6492 & $0.0000^{*}$ \\
2. & BANKING & 0.9996 & $0.0005^{*}$ & 0.9993 & $0.0005^{*}$ \\
3. & MUTUAL FUND & 0.9997 & $0.0280^{*}$ & 0.9988 & $0.0182^{*}$ \\
4. & STOCK & 0.0584 & $0.0000^{*}$ & 0.0582 & $0.0000^{*}$ \\
5. & SUKUK & 0.9977 & $0.0003^{*}$ & 0.9985 & $0.0003^{*}$ \\
\hline
\end{tabular}

*p-value < 0.05. Stasic at level 5\%

Source: Processed Data 


\section{Determination of the Optimum Lag}

Determination of the amount of Lag that is used must be determined to process the data. The optimum Lag is a way to choose how much Lag we will use in the study, so selecting the optimum amount of Lag is necessary to get better results. This study will look at the optimum amount of Lag based on the lag length criteria VAR results. The most optimum lag results are shown from the highest number of stars. The results of the lag length criteria used in this estimation model are lag 1.

Table 3.

Optimum Lag Test Results

\begin{tabular}{crlllll}
\hline Lag & LogL & \multicolumn{1}{c}{ LR } & \multicolumn{1}{c}{ FPE } & AIC & \multicolumn{1}{c}{ SC } & HQ \\
\hline 0 & -998.2439 & NA & $1.62 \mathrm{e}+25$ & 69.39613 & 69.77331 & 69.51426 \\
1 & -928.4517 & $110.7048^{*}$ & $4.05 \mathrm{e}+23^{*}$ & $65.68633^{*}$ & $66.81788^{*}$ & $66.04071^{*}$ \\
2 & -918.3963 & 13.17609 & $6.71 \mathrm{e}+23$ & 66.09629 & 67.98222 & 66.68694 \\
\hline
\end{tabular}

Source: Processed Data

\section{Robustness Test}

Table 4.

Robustness Test Results

\begin{tabular}{lccc} 
& Value & Df & Probability \\
\cline { 2 - 4 } t-statistic & 0.569399 & 26 & 0.5740 \\
F-statistic & 0.324215 & $(1,26)$ & 0.5740
\end{tabular}

F-test summary:

\begin{tabular}{lccc}
\hline & Sum of Sq. & df & Mean Squares \\
\cline { 2 - 4 } Test SSR & $6.30 \mathrm{E}+08$ & 1 & $6.30 \mathrm{E}+08$ \\
Restricted SSR & $5.12 \mathrm{E}+10$ & 27 & $1.90 \mathrm{E}+09$ \\
Unrestricted SSR & $5.05 \mathrm{E}+10$ & 26 & $1.94 \mathrm{E}+09$ \\
\hline
\end{tabular}

Source: Processed Data

To see the linearity of the model, it is necessary to do the Ramsey Reset test. The Ramsey Reset Test also tests whether the model is BLUE (Best Linear Unbiased Estimation). To see the Ramsey Reset test results in the model above, we can see the p-value shown in the probability column on Fstatistics. Based on the test results above, it can be concluded that the independent variable is linear with the dependent variable because $p$-value $=0.5740>0,05$.

\section{ARDL Model Diagnostic Test}

The diagnostic test of the ARDL model is used to find out more clearly whether the resulting ARDL model is suitable and perfect. To perform a diagnostic test, we first need to check the results of the Bound Test. The Bound Test is used to see how much the percentage significance we can use for the variables we are studying. The results of the Bound Test in Table 5 show the F statistical value of 2.758734. This value is below the I1 value. This shows that the ARDL estimation results can be used up to the significance of $\alpha=1 \%$. This result also shows that the variables do not have a long-term cointegration relationship. This has implications for the Islamic financial sector, which does not affect national income in the long run.

Table 5.

ARDL Bound Test

\begin{tabular}{ccc}
\hline Test Statistic & Value & $\mathrm{k}$ \\
\hline F-statistic & 2.468688 & 4 \\
\hline Critical Value Bounds & & \\
\hline Significance & I0 Bound & I1 Bound \\
\hline $10 \%$ & 2.45 & 3.52 \\
$5 \%$ & 2.86 & 4.01 \\
$2.5 \%$ & 3.25 & 4.49 \\
$1 \%$ & 3.74 & 5.06 \\
\hline
\end{tabular}

Source: Processed Data 
The results examined are the value of the error-correlation coefficient $(\mathrm{CointEq}(-1))$ in the short-term ECM model. This value will indicate how much error will be corrected in each time period. To qualify, this value must be negative and significant. Table 6 shows that the value of CointEq(-1) in this model is -0.814301 with a probability of 0.0001 , the value is negative and significant as expected. This shows that $81.43 \%$ of errors in the data will be corrected in each time period.

Table 5.

Error-Correlation Coefficient

\begin{tabular}{ccccc}
\hline Variable & Coefficient & Std. Error & t-Statistic & Prob. \\
\hline CointEq(-1) & -0.814301 & 0.173650 & -4.689329 & 0.0001 \\
\hline
\end{tabular}

Source: Processed Data, 2021.

\section{ECM Short Term Analysis}

The short-term results of the ARDL model can be seen from the ECM model obtained. This ECM model is obtained by using the general to specific method starting from the maximum lag and then with standard test procedures eliminating the ARDL variables that are not specifically significant so that the simplest result (parsimonious regression) is obtained. The following table 7 shows the shortterm estimation results for the ECM.

Table 7.

Short Term Estimation Results

\begin{tabular}{ccccc}
\hline Variabel & Coefficient & Std. Error & t-Statistic & \multicolumn{1}{c}{ Prob. } \\
\hline D(BANKING) & 8.398965 & 1.950404 & 4.306269 & $0.0002^{*}$ \\
D(MUTUAL FUND) & -5.804648 & 1.959298 & -2.962616 & $0.0063^{*}$ \\
D(STOCK) & 16.492125 & 53.040013 & 0.310937 & 0.7582 \\
D(SUKUK) & -11.592016 & 6.603881 & -1.755334 & $0.0905^{* *}$ \\
CointEq(-1) & -0.814301 & 0.173650 & -4.689329 & 0.0001 \\
\hline
\end{tabular}

Source: Processed Data

Ket: $*$ p-value $<0.05, * *$ p-value $<0.10$

The short-term estimation from table 7 shows that in the short term the banking variable has a positive and significant effect on GDP, while the mutual funds and sukuk variables have a negative and significant effect on GDP. Sharia stock variables have no significant effect on GDP.

\section{ARDL Long-Term Analysis}

ARDL long-term estimation can analyze the long-term relationship when the explanatory variables are a mixture of I (1) and I (0). The ARDL estimator will produce consistent long-run coefficients and resulting estimates are consistent with good long-term coefficients regardless of whether the explanatory variables or regressors are I (0) or I (1). The following table 8 shows the longterm estimation results of the ARDL.

Table 6.

Long-Term Estimation ARDL

\begin{tabular}{|c|ccc|c|}
\hline Variabel & Coefficient & Std. Error & t-Statistic & Prob. \\
\hline BANKING & 10.314324 & 1.312388 & 7.859202 & $0.0000^{*}$ \\
MUTUAL FUND & -7.128380 & 2.367570 & -3.010843 & $0.0056^{*}$ \\
STOCK & 20.253107 & 64.767242 & 0.312706 & 0.7569 \\
SUKUK & -14.235541 & 7.511252 & -1.895229 & $0.0688^{* *}$ \\
C & 1708358.574628 & 100008.201832 & 17.082185 & 0.0000 \\
\hline
\end{tabular}

Source : Processed Data

Ket: *p-value $<0.05, * *$ p-value $<0.10$

The long-term ARDL estimation from the table above shows that the banking and sukuk variables have significant and positive results on GDP, while the mutual funds and stocks variables have a negative but not significant value on GDP. The equations formed from the table are as follows:

$$
\begin{aligned}
\text { GDP_LN }= & 1708358.574628+10.314324 * \text { BANKING }-7.128380 * \text { MUTUAL } \\
& \text { FUND }+20.253107 * \text { STOCK }-14.235541 * \text { SUKUK }
\end{aligned}
$$




\section{The Effect of Islamic Banking on National Income patan Nasional}

The short-term estimation from table 7 shows that the banking variable has a significant positive effect on GDP with a probability value of $0.0002<0.05$. The coefficient of the Islamic banking variable, in this case the mudharabah and musyarakah financing, is positive, namely 8.398965 . This means that in the short term an increase of 1 billion in mudharabah and musyarakah financing will increase GDP by 8.398965 billion in the following quarter.

The long-term estimation from table 8 shows that the Islamic banking variable has a positive significant effect on GDP with a probability value of $0.0000<0.05$. The coefficient of the Islamic banking variable is positive, namely 10.314324. This means that in the long term an increase of 1 billion in mudharabah and musyarakah financing will increase GDP by 10.314324 billion in the following quarter.

This implies that the mudharabah and musyarakah financing sectors of Islamic banking have a significant influence on increasing the productive sector in Indonesia through financing business activities in order to increase the role of Islamic banking in Indonesia's national income so that in the long term it is expected to be able to support national income and the Indonesian economy through productive activities. which is conducted. This is in accordance with Schumpeter's theory on the finance-led growth hypothesis or supply-leading view related to the production function theory, which shows that the financial sector encourages economic growth. Islamic banking encourages long-term economic growth through the intermediary function of banks that channel funds from the owners of funds and distribute them to parties who need funds. Then the funds are channeled by Islamic banking through the existing economic sectors in the community such as financing for working capital, financing for investment and financing for consumption. Ayyubi, Anggraeni, \& Mahiswari (2017) state that a causal relationship supports the existence of bidirectional causality between Islamic banking and economic growth in Indonesia.

This research is also in line with Rama (2013) which states that the growth of Islamic banking in Indonesia can encourage high economic expansion through forms of products and services that are sharia-compliant. Of course, this is in line with the character of Islamic banking itself which is very pro and emphasizes the real economic sector.

\section{The Effect of Sharia Mutual Funds on National Income}

The short-term estimation from table 7 shows that the Islamic mutual fund variable has a significant negative effect on GDP, with a probability value of $0.0063<0.05$. The mutual fund variable coefficient, in this case the net asset value of sharia mutual funds, is negative, namely -5.804648 . This means that in the short term an increase of 1 billion in net asset value of Islamic mutual funds will reduce GDP by 5.804648 billion in the next quarter.

The long-term estimation from table 8 shows that the Islamic mutual fund variable has a significant negative effect on GDP with a probability value of $0.0056<0.05$. The coefficient of the Islamic banking variable is negative, namely -7.128380 . This means that in the long term an increase of 1 billion in net asset value of Islamic mutual funds will reduce GDP by 7.128380 billion in the next quarter.

This is due to the low level of sharia mutual funds in Indonesia, one of which is the lack of socialization carried out by the securities providers of sharia mutual funds to invite their customers to invest in sharia mutual funds. Sharia mutual funds have a relatively the same role as stocks whose income from sharia mutual funds is still within the scope of the criteria for sharia mutual fund companies, so that their influence on national economic growth is not directly or comprehensively. Similar to Islamic stocks, the market capitalization of Islamic mutual funds also depends on the productivity and performance of the companies that are members of the Islamic mutual funds. In addition, the NAV capitalization of sharia mutual funds is also still low compared to the NAV capitalization of conventional mutual funds so that it has not had a positive impact on the country's national income.

Kharissa Dinna (2019) in his research also states that Islamic mutual funds have a negative and insignificant effect on economic growth. This happens because even though it is seen from the prospect of the development of sharia mutual funds themselves growing quite rapidly but it does not directly affect the Gross Domestic Product because the results of these investments affect the scope of 
individuals or the private sector.

The results of other studies which state that Islamic mutual funds have a negative effect on Indonesia's national income illustrate that this influence is due to the volatile conditions of Islamic mutual funds influenced by the condition of economic stability in the country as well as the condition of Islamic stocks which also have a negative correlation with national income. It is hoped that the demand from Islamic capital market investors and the demand from Islamic capital market investors and supply in terms of Islamic capital market products will not mismatch due to the limited investment products in the Islamic capital market. In addition, the opportunities for the Islamic capital market, both stocks and sharia mutual funds, are increasingly wide open with the trend towards sharia-based investment which has continued to increase recently.

\section{The Effect of Sharia Stock Index on National Income}

The short-term estimation from table 7 shows that the Islamic stock variable has no effect on GDP with a probability value of $0.7582>0.10$. Likewise, the long-term estimation from table 8 shows that the Islamic stock variable has no effect on GDP with a probability value of $0.7569<0.05$. It means that

This is due to the small capitalization of sharia shares incorporated in the Indonesian Sharia Stock Index (ISSI) against the capitalization of conventional shares. The conventional capital market has a higher number of registered companies and a larger capital capitalization value so that it is able to have a greater impact on national income and Gross Domestic Product (GDP). Theoretically, it can be explained that the increase in economic growth can increase the purchasing power of consumers towards the company's products, thereby increasing the profitability of the company.

Changes in stock prices will affect the income of Islamic shares that affect economic growth. Because economic growth determines economic development. In recent years, Indonesia's economic growth has decreased due to the impact of the crisis in 2008 and the financial crisis in European countries in 2013. Indicators of a country's economic decline can be seen from the decline in stock prices in the Indonesian Sharia Stock Index (ISSI). . If there is an increase in profitability, it will increase investors in investing, so that it can increase stock prices which will have a positive impact. Therefore, income from sharia shares is still within the scope of the criteria for shariah stock companies, so that their influence on national economic growth is not directly or comprehensively. In addition, unstable market pressures and a lot of speculation also encourage people to choose a clearer investment sector such as gold or deposits. This is in accordance with research from Radjak and Kartika (2018) which found a negative influence between Islamic stock prices on economic growth in Indonesia because Islamic stock prices are influenced by economic stability conditions in the country. The Islamic stock index can improve if the economy in the country is also improving, thereby encouraging economic activity through investment.

Different research results are shown by Fauzan and Suhendro (2019) which state that the development of the Islamic capital market from 2000 to 2016 has a role in Indonesia's Gross Domestic Product (GDP) which is reflected in the main indicators in the capital market which continues to grow from year to year. as well as being able to become a driver of economic growth by increasing investment activities. This increase was driven by, among other things, the start of the formation of the Indonesian capital market capitalization which indicates that the Islamic capital market has a fairly large role in encouraging Indonesia's economic growth. The Jakarta Islamic Index often shows fluctuating movements due to several factors, namely low bank interest rates, coupled with improving foreign investors' perceptions of the level of risk in Indonesia, as well as a significant interest differential; and the stability of macroeconomic indicators and the prospect of a significant increase in economic growth in the midst of a sluggish global economy have resulted in foreign investors starting to look to the Indonesian capital market.

\section{The Effect of Sharia Bonds on National Income}

The short-term estimation from table 7 shows that the Islamic bond variable has a significant negative effect on GDP with a probability value of $0.0905<0.10$. The variable coefficient of Islamic bonds, in this case the outstanding value of Islamic bonds is negative, which is -11.592016 . This means that in the short term an increase of 1 billion in the outstanding value of Islamic bonds will reduce GDP by 11.592016 billion in the next quarter. 
Long-term estimates from table 8 show that the Islamic bond variable has a significant negative effect on GDP with a probability value of $0.0688<0.10$. The variable coefficient of Islamic bonds is negative, namely -14.235541 . This means that in the long term an increase of 1 billion in the outstanding value of Islamic bonds will reduce GDP by 14.235541 billion in the next quarter.

The negative effect of Islamic bonds is due to the low number of issuance of Islamic bonds in Indonesia. This is reinforced by the low outstanding value of state sukuk, which is Rp. 1,597.75 trillion with a market share of state sukuk which is only $18.58 \%$ in Indonesia. Nur Faroh's research (2016) states that Islamic bonds should be very reliable and useful for the state as a tool for capital mobilization purposes, as well as a means for the private sector to finance projects of public interest, as an instrument in promoting domestic and international investment, in addition to being able to useful for the process of fiscal decentralization. Nurafiati (2019) stated that Islamic bonds or sukuk are financial instruments that are growing rapidly in line with the growth and development of other conventional financial instruments. Sukuk is a type of investment that is beneficial for companies and investors, both state and private.

The issuance of state sukuk is based on the government wanting other sources of funds to increase the State Revenue and Expenditure Budget (APBN) through an expansive fiscal policy as stated in Article 4 of the State Sharia Securities Law, namely that the purpose of issuing SBSN is to finance the APBN including financing project development. Projects that can be financed with state sukuk are the energy, telecommunications, transportation, agriculture, manufacturing and housing industries. The results of this study are in line with Beik's research (2011) which states that the issuance of state sukuk is currently dominated by efforts to fill the APBN deficit in infrastructure development in order to achieve stable national income and increasing economic growth. This shows that sukuk can affect national income so that it continues to be stable.

\section{The Influence of the Islamic Finance Sector on National Income}

Simultaneous testing of the four variables constituting the Islamic finance sector using the Bound Test shows an F statistic of 2.468688. This value is below the value of I1. This shows that the ARDL estimation results can be used up to a significance of $=1 \%$, and this result also shows that there is no long-term cointegration relationship between variables. This has implications for the Islamic finance sector which in the long run does not affect national income. The financial sector plays an important role in increasing economic growth through the mobilization of financial resources and capital or investment inflows. Both can take advantage of various financial instruments in the capital market to fund various long-term projects. For example, the government can issue sukuk to build road infrastructure, build hospitals, public transportation, build dams, airports, and other social infrastructure. This will certainly encourage the creation of state wealth and certainly have an impact on domestic economic growth. As a supporting theory, there is the theory from Harrod-Domar which analyzes the conditions needed for the economy to grow and develop in the long term. In other words, this theory provides a necessary condition so that the economy can grow and develop progressively, one of which is investment through the financial sector in the long term.

The results of this study are in line with Kassim's (2016) research which measures the influence of the Islamic finance sector in Malaysia. The results of this study indicate that Islamic banks in Malaysia effectively carry out the role of financial intermediation in collecting and distributing funds to productive investment activities. The contribution of the Islamic finance sector to real economic activities can certainly be realized by the presence of capital in it. Therefore, the relationship between investors and Islamic banking must work well to increase productivity. The Islamic finance sector is considered more stable because there is no interest rate risk, the risk of loss can be reduced to a lower level through investment cooperation contracts such as mudharabah or musharaka for productive activities. In terms of financing, although the Islamic finance sector in Malaysia has a long-term and long-term impact, the long-term effect has proven to be stronger than the short-term, so banks need to balance the allocation of funds to plan other business expansions.

\section{CONCLUSION}

This study aims to analyze the short-term and long-term relationship between the Islamic finance sector and national income in Indonesia in 2011 to 2020. The ARDL test was conducted to see 
whether there was a short-term and long-term relationship between variables. The results partially show that in the short term, Islamic banking has a positive positive effect on GDP, Islamic stocks and Islamic mutual funds have a negative effect on GDP, while Islamic bonds have no effect on GDP. In the long term, Islamic banking has a positive positive effect on GDP, Islamic stocks and Islamic mutual funds have a negative effect on GDP, while Islamic bonds have no effect on GDP. The results of this study also show that there is no long-term cointegration relationship between variables. This has implications for the Islamic finance sector which in the long run does not affect national income. The limitation in this study is that there are still few sources of supporting literature that discuss the Islamic finance sector simultaneously, most of the previous research available is research with partial variables, making it difficult for the author to collect various supporting literature.

\section{REFERENCES}

Abduh, M., \& Omar, M. A. (2012). Islamic banking and economic growth: The Indonesian experience. International Journal of Islamic and Middle Eastern Finance and Management, 5(1), 35-47.

Al-tamimi, K. (2018). The role of Islamic banks operating in Jordan in economic development. Journal of Economics and Sustainable Development, 4(8), 46-59.

Ayyubi, S. E., Lukytawati, A., \& Almira, D. M. (2017). Pengaruh bank syariah terhadap pertumbuhan ekonomi di Indonesia. Jurnal Al-Muzara'ah, 5(2), 88-106.

Badan Koordinasi Penanaman Modal. (2018). Realisasi Investasi PMA Berdasarkan Lokasi. Retrieved from

https://www.bkpm.go.id/images/uploads/investasi_indonesia/file/Realisasi_FDI_berdasarkan_ lokasi_Jan-Des_2018.pdf.

Beik, I. S. (2011). Memperkuat Peran Sukuk Negara Dalam Pembangunan Ekonomi Indonesia. Jurnal Ekonomi Islam Al-Infaq, 2(2), 65-72.

Faroh, N. (2016). Pengaruh saham syariah, sukuk, dan reksadana syariah terhadap pertumbuhan ekonomi nasional (tahun 2008-2015). Skripsi tidak diterbitkan. Tulungagung: IAIN Tulungagung.

Fauzan, M., \& Suhendro, D. (2019). Peran pasar modal syariah dalam mendorong laju pertumbuhan ekonomi di Indonesia. Human Falah: Jurnal Ekonomi dan Bisnis Islam, 5(1), 69-95.

Hayati, S. R. (2014). Peran perbankan syariah terhadap pertumbuhan ekonomi Indonesia. IndoIslamika, 4, 41-66.

Kakwani, N., Son, H., \& Asian Development Bank. (2003). Pro-Poor Growth: Concepts and measurement with country case studies. Working Paper, 1-24.

Kassim, S. (2016). Islamic finance and economic growth: The Malaysian experience. Global Finance Journal, 30, 66-76. http://dx.doi.org/10.1016/j.gfj.2015.11.007.

Nasution, Y. S. J. (2015). Peranan pasar modal dalam perekonomian negara. Human Falah: Jurnal Ekonomi dan Bisnis Islam, 2(1), 95-112.

Nurafiati, N. (2019). Perkembangan pasar modal syariah dan kontribusinya terhadap pertumbuhan ekonomi di Indonesia. Inklusif (Jurnal Pengkajian Penelitian Ekonomi Dan Hukum Islam), $4(1), 65-75$.

Radjak, L. I., \& Kartika, I. Y. (2018). Pengaruh saham syariah terhadap pertumbuhan ekonomi nasional. Journal Syariah and Accounting Public, 2(1), 60-70.

Rama, A. (2013). Perbankan syariah dan pertumbuhan ekonomi Indonesia. Signifikan: Jurnal Ilmu Ekonomi, 2(1), 33-56.

Rasyad, R. (2012). Perbankan syariah dan pertumbuhan ekonomi Indonesia. Signifikan: Jurnal Ilmu Ekonomi, 2(1), 33-56.

Rosadi, D. (2011). Analisis ekonometrika dan runtun waktu terapan. Yogyakarta: Offset.

Schumpeter, J. (2013). Schumpeter's View on Innovation and Entrepreneurship. SSRN Electronic Journal (October). Retrieved from https://www.researchgate.net/publication/256060978.

Shin, Y., \& Smith, R. J. (2001). Bounds testing approaches to the analysis, 326(February), 289-326. 